\title{
Ionotropic neurotransmitter receptors: activation and allosteric modulation
}

\author{
Gábor Maksay*1 and László Fodor²
}

\author{
Address: ${ }^{1}$ Department of Molecular Pharmacology, Institute of Biomolecular Chemistry, CRC-HAS, Budapest, Hungary and ${ }^{2}$ Department of \\ Pharmacology, G. Richter Plc., Budapest, Hungary \\ Email: Gábor Maksay* - maksay@chemres.hu \\ * Corresponding author
}

\author{
from I3th Scientific Symposium of the Austrian Pharmacological Society (APHAR). Joint Meeting with the Austrian Society of Toxicology (ASTOX) and the \\ Hungarian Society for Experimental and Clinical Pharmacology (MFT) \\ Vienna, Austria. 22-24 November 2007 \\ Published: 14 November 2007 \\ BMC Pharmacology 2007, 7(Suppl 2):A37 doi:I0.I I86/I47I-22I 0-7-S2-A37
}

This abstract is available from: http://www.biomedcentral.com/I47I-22I0/7/S2/A37

(c) 2007 Maksay and Fodor; licensee BioMed Central Ltd.

\section{Introduction}

GABA and glycine are major inhibitory neurotransmitters. $\mathrm{GABA}_{\mathrm{A}}$ and glycine receptors (GlyR) form pentameric chloride channels and belong to the Cys-loop receptor superfamily with $5-\mathrm{HT}_{3}$ serotonin and nicotinic receptors. Homology modelling has revealed distinctive binding interactions of antagonists and agonists in the interface of $5-\mathrm{HT}_{3 \mathrm{~A}}$ receptors leading to ligand translocation, closure of the binding cavity and ionophore activation. Allosteric modulation of ionotropic receptors enables the pharmacological fine-tuning of neurotransmission.

\section{Methods}

Radioligand binding of $\left[{ }^{3} \mathrm{H}\right] \mathrm{EBOB}$ and $\left[{ }^{3} \mathrm{H}\right]$ strychnine to native $\mathrm{GABA}_{\mathrm{A}}$ and recombinant GlyRs, respectively, and whole-cell patch clamp electrophysiology in cultured rat cerebellar granule cells.

\section{Results}

A $17 \beta$-alkenyl derivative of the neurosteroid allopregnanolone antagonized the potentiating effects of allopregnanolone selectively on a cerebellar $(\alpha 6 \beta \delta)$ population of $\mathrm{GABA}_{\mathrm{A}}$ receptors with nanomolar potency. Nortropine esters exerted bidirectional allosteric modulation of GlyRs: nor-O-zatosetron had the highest affinity reported for GlyRs. The anaesthetic propofol restored the potency of glycine impaired by a point mutation R271L of GlyR $\alpha 1$ subunits leading to hyperekplexia, an inherited neurological disorder.

\section{Conclusion}

Some of these allosteric modulators have nanomolar potencies and serve as promising leads for subunit-selective modulation of ionotropic receptors.

\section{Acknowledgements}

Support: OTKA K-62203. 